Original Research Paper

\title{
Germination Study and Monitoring in the Nursery of Young Seedlings of Garcinia mangostana $\mathbf{L}$.
}

\author{
${ }^{1}$ Haba Jean Florent, ${ }^{2}$ Dembele Ardjouma, ${ }^{1}$ Koffi Kouao Jean, ${ }^{1}$ Phaceli Elichama Desirée and ${ }^{3}$ Silué Nakpalo \\ ${ }^{1}$ Department of Natural Sciences, Nangui Abrogoua University, Abidjan, Côte d'Ivoire, Abidjan \\ ${ }^{2}$ National Laboratory for Agricultural Development Support (LANADA), Central Laboratory for Agro Chemistry \\ and Ecotoxicology (LCAE), Abidjan, Côte d'Ivoire, Abidjan \\ ${ }^{3}$ Laboratory of Vegetable Physiology, Agrophysiology, Felix Houphouet Boigny University, Abidjan, Côte d'Ivoire, Abidjan
}

\section{Article history}

Received: 30-04-2021

Revised: 28-06-2021

Accepted:29-07-2021

Corresponding Author:

Haba Jean Florent

Department of Natural

Sciences, Nangui Abrogoua

University, Abidjan, Côte

d'Ivoire.

Email: hjeanflorent@gmail.com

\begin{abstract}
Mangosteen tree (Garcinia mangostana L.) is a plant of the Clusiaceae family cultivated for its particular taste and for its excellent medicinal properties. However, the vegetative propagation of the plant by cuttings or grafting being difficult to achieve, seed germination remains the main means of production used. This study was therefore initiated with the aim of determining the influence of three factors namely the type of seed used as seed, the mass of the seed and the soil used as a substrate on the germination parameters and on the growth of seedlings in nursery in Côte d'Ivoire. To do this, the germination parameters of seeds that received three different pretreatments (wasteland seeds, dried seeds and cold stored seeds), seeds of different masses (less than $1 \mathrm{~g}$ and more than $2 \mathrm{~g}$ ) as well as seeds germinated on several substrates (Petri dish, forest soil, lowland soil and construction sand) were evaluated. The results obtained showed that the germination of the mangosteen seed is significantly influenced by the three factors studied. The best time, speed and germination rate were obtained with fresh seeds and seeds of masses greater than $2 \mathrm{~g}$. As for the type of substrate, the highest germination rate was obtained with the seeds germinated in the Petri dishes (99\%). Regarding the monitoring of seedlings in the nursery, those from seeds with a mass greater than $2 \mathrm{~g}$ evolving on lowland soil recorded the best growth performance.
\end{abstract}

Keywords: Mangosteen, Seed Germination, Garcinia mangostana, Côte d'Ivoire

\section{Introduction}

Mangosteen (Garcinia mangostana L.) is a tropical fruit tree of the Clusiaceae family. Native to Southeast Asia, it is mainly grown in South Vietnam, Cambodia, Indonesia and Thailand (Osman et al., 2006). Thailand remains to this day the main producer country with 240,000 tonnes of fruit produced per year (Lim et al., 2013). Mangosteen is unanimously recognized as one of the best tropical fruits. Apart from its highly regarded taste which has earned it the designation "queen of fruits", mangosteen is also cultivated for its excellent medicinal properties. Most studies show that this fruit has remarkable antioxidant, antitumor, antiallergic, anti-inflammatory, antibacterial and antiviral properties which therefore allow it to fight against a very varied range of diseases (Kondo et al., 2009; Zhang et al., 2016). It is precisely the abundance of xanthones (biologically active phenolic compounds with more effective antioxidant properties than vitamins $\mathrm{C}$ and $\mathrm{E}$ ) that gives this fruit these therapeutic virtues (Karim et al., 2020).

In Côte d'Ivoire, mangosteen cultivation was introduced in 1970 through the fruit program of the Azaguié Fruit Research Institute (IRFA). Since then, the lack of a technical itinerary, the more or less complex requirements and the very slow growth of the plant have constituted a real obstacle to its cultivation (Dembélé, 2013). The cultivation of mangosteen was therefore limited to small farms owned by individuals unlike certain fruit crops such as bananas, pineapples and mangoes etc. There is indeed very little information and scientific data on cultivation techniques and therefore on the procedures to be followed for the establishment of mangosteen cultivation in Côte d'Ivoire. The vegetative propagation of the plant by cuttings or grafting being difficult to achieve, the germination of seeds remains the main means of production used. However, the optimal conditions of the process of germanization of the seeds of this plant, which remains a 
very essential stage in the establishment of its culture, remain unknown. According to Bourdeaut and Moreuil (1970) the germination success rate in the mangosteen tree would depend on the one hand on the edaphic parameters and on the other hand on the type of seed used as seed. In such a context it is necessary to have precise information on the factors favoring a better germination of the seed of Garcinia mangostana L. Specifically it will be for us to determine the influence of the type of seed used as seed, the mass of the seed and the soil used as a substrate on the success rate of germination and on the growth of seedlings in the nursery.

\section{Materials and Methods}

\section{Study Area}

The study was carried out in the locality of Azaguie located in the south-east of Côte d'Ivoire, about $40 \mathrm{~km}$ north of the District of Abidjan. The town's geographic coordinates are $5^{\circ} 35$ and $6^{\circ} 15$ North latitude and $3^{\circ} 55$ and $4^{\circ} 40$ West longitude (N'guessan, 2015). The locality of Azaguié is subject to a humid tropical climate of the Attiean type. It has two rainy seasons alternated by two dry seasons. The average rainfall in this region oscillates between 1250 and $1500 \mathrm{~mm}$ for an average annual temperature of $28^{\circ} \mathrm{C}$ (Ahoussi et al., 2013). This locality is characterized by a strong predominance of modern farms.

\section{Biological Material}

The plant material used consisted of Garcinia mangostana seeds from healthy fruits harvested manually from 10-year-old mangosteen trees identified for their productivity and seed qualities. These seeds were extracted from the fruits harvested during the month of May of the year 2020. The seeds used were selected by manual sorting according to their vigor and their physiological state (Fig. 1).

\section{Factors Studied}

The influence of three abiotic factors on the germination capacity of Garcinia mangostana seed has been studied. This concerns the type of seed used as seed, the mass of the seeds and the nature of the substrate.

\section{Influence of the Type of Seed}

For the evaluation of this factor, Garcinia mangostana seeds received three pretreatments. These include drying in the shade at room temperature for 14 days, cold storage at $4^{\circ} \mathrm{C}$ for 30 days and freshly harvested seeds. The average masses of the fresh and dried seeds were respectively $1.8 \pm 0.03 \mathrm{~g}$ and $0.85 \pm 0.015 \mathrm{~g}$, i.e., a variable humidity level of $52.77 \%$.

\section{Influence of Seed Mass}

The effect of seed mass was evaluated by composing two batches of seeds of different mass. Seeds with a mass of less than $1 \mathrm{~g}$ were used as a small seed and those with a mass greater than $2 \mathrm{~g}$ were used as a large seed. The mean masses of the seeds used were respectively $0.92 \pm 0.22 \mathrm{~g}$ for the small seeds and $2.4 \pm 0.14 \mathrm{~g}$ for the large seeds.

\section{Influence of Nature and Substrate}

Seeds were first germinated in Petri dishes in laboratory then by direct sowing in three types of substrates including forest soil and lowland soil (main soils recommended for growing mangosteen) and sand construction (known to be good for the pre-germination of seeds (Bita et al., 2017). The soils used were collected at the experimental site, one in a lowland sheltering producing mangosteen trees and the other in the forest undergrowth. The sand used was fine sand from the bottom of the lagoon waters.

\section{Experimental Setup}

Germination in the laboratory was carried out in transparent plastic mini-trays $(15 \mathrm{~cm}$ wide, $25 \mathrm{~cm}$ long and $7.5 \mathrm{~cm}$ high) used as culture medium. The inside of the tanks was covered with blotting paper and then soaked in bi-distilled water and fresh mangosteen seeds were germinated in these media without prior pretreatment (Dembélé, 2013). Ten seeds were placed in each hermetically sealed mini-trays and stored at room temperature, protected from light. The germination parameters of 150 seeds placed in 15 trays were evaluated on this substrate.

For the tests carried out in the three types of soil, soils from forest, lowland as well as construction sand were used. Perforated polyethylene bags of approximately 10 holes 4 $\mathrm{mm}$ in diameter were filled with each type of substrate. They were carefully arranged in rows of 10 separated by $15 \mathrm{~cm}$ under a shade. Spaces of $60 \mathrm{~cm}$ have been planned between the lines to allow easier circulation during watering. One mangosteen seed was added to each sachet on the same day to a depth of approximately $2 \mathrm{~cm}$. The device thus constituted was subject to regular watering in order to maintain constant humidity in the environments (Bourdeaut and Moreuil, 1970; Laouali et al., 2015). For each type of seed and soil, the germination parameters of 100 seeds were evaluated.

\section{Parameters Evaluated}

The agronomic parameters of germination namely Germination Delay (GD), Germination Rate (GR), Speed of Germination (SG) and seedling Survival Rate (SR) were evaluated over 30 days.

\section{Germination Delay (GD)}

Germination delay is the time between sowing the seeds and observing the first germination. It was determined for each type of seed and substrate. This parameter was evaluated taking into account the first day after sowing.

\section{Germination Rate (GR)}

Germination rate assessment consisted of determining the germination potential of the mangosteen seeds. This 
parameter was measured by taking the ratio of the number of seeds having germinated by the total number of seeds sown. For the test carried out in the laboratory, the radicle emission was retained as the germination criterion (Bamba et al., 2018). As for the test by direct sowing, the emergence of seedlings was considered as the germination criterion. The germination rate was determined using the following formula 1 :

$$
G R=\frac{n}{N} \times 100
$$

Where:

$G R=$ Germination rate $(\%)$

$N=$ number of sown seeds

$n$ = number of germinated seeds

\section{Speed of Germination (SG)}

Speed of germination was also evaluated. It consisted in determining the Mean Germination Time (GMT) which corresponds to the time after which $50 \%$ of the seeds germinated. This parameter was evaluated for each substrate and each type of seed (Berka et al., 2001). This germination rate was calculated using the following formula 2 :

$$
S G=\sum_{i=1}^{i=n} \frac{n i \times t i}{N}
$$

Where:

$\mathrm{SG}=$ Average time of germination

$N i=$ The number of germinated seeds at time ti

$N=$ The number of germinated seeds at the end of the trial

\section{Survival Rate (SR)}

Three months after the emergence of the seedlings, the wilted and stunted plants were discarded in order to retain the more vigorous ones which are considered viable young plants. This parameter was calculated according to the following formula 3 :

$S R=\frac{N P}{N G} \times 100$

Where:

$S R=$ Survival rate,

$N P=$ Number of viable plants,

$N G=$ Total number of plants resulting from germination

\section{Monitoring of Seedling Growth in Nurseries}

Seedlings were monitored in order to study the growth of the mangosteen tree in the nursery. The influence of seed mass and type of substrate on plant growth was evaluated. Young plants from seeds with a mass less than $1 \mathrm{~g}$ and greater than $2 \mathrm{~g}$ as well as those which germinated on the two types of soil were followed for 24 weeks (6 months). The growth parameters evaluated were:

- Stem height (measured weekly with a ruler graduated to the millimeter),

- leaf length and width (measured weekly with a ruler graduated to the millimeter),

- the length of the main root (measured at the end of the test with a ruler graduated to the millimeter)

\section{Statistical Analysis}

The data obtained were subjected to statistical analyzes. The XLSTAT software was used for this purpose. One-way Analysis of Variance (ANOVA) and Student's t-test were used to assess the significant effect of different treatments on the germination and growth parameters of young plants. In the event of a significant difference, multiple comparisons of the means were carried out using the Tukey test at the 5\% level and when the conditions for normality were not met, the Mann-Whitney U test (nonparametric) allowed further analyzes.

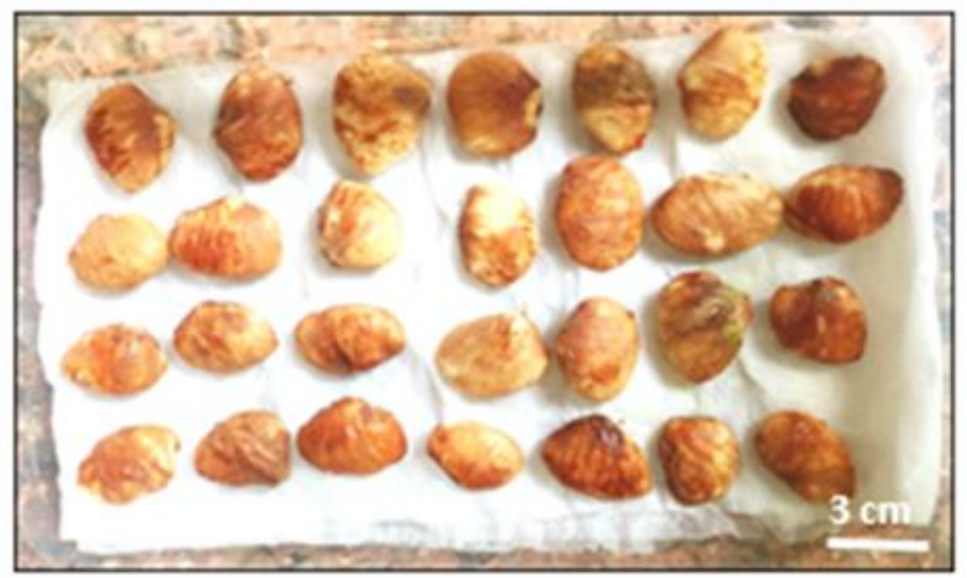

Fig. 1: Seeds of Garcinia mangostana 


\section{Results}

\section{Influence of Seed Type on Germination Parameters}

\section{Germination Delay (GD)}

Of the three types of seeds namely Fresh Seeds (FS), Frozen Seeds (FrS) and Dried Seeds (DS), fresh seeds recorded the best germination time which is 16 days. Seeds stored in the freezer had a germination time of 18 days. With shade-dried seeds, the germination time was 20 days.

\section{Germination Rate (GR)}

Analysis of the results revealed that the cumulative germination rate 30 days after sowing is significantly affected by the nature of the seed. Indeed, the highest germination rate $(80 \%)$ was obtained with fresh seeds. According to Tukey's HSD test, this value is significantly different from that obtained with dried seeds $(60 \%)$. As for seeds stored in the freezer, they recorded the lowest germination rate $(42.5 \%)$. This rate is statistically different from the rates recorded with the two previous types of seeds.

\section{Speed of Germination ( $S G$ )}

The germination rate determined through the mean germination time was 16.5 days for fresh seeds and 22.5 days for dried seeds. This rate could not be determined for seeds stored in the freezer due to the germination rate of less than $50 \%$. The mean germination times obtained with the two types of seeds are significantly different according to Student's $t$ test. The curve of the cumulative germination rate as a function of the number of days after sowing is shown in Fig. 2.

\section{Survival Rate (SR)}

Evaluation of the survival rate of seedlings from seed types revealed that this parameter is weakly influenced by pretreatment. This rate was $99.33 \%$ for all seedlings that germinated. Dried seeds were the only ones with death rates. However, this rate was relatively low $(2 \%)$.

\section{Influence of Seed Mass on Germination Parameters}

\section{Germination Delay (GD)}

The evaluation of germination delay showed that the first seedlings of Garcinia mangostana seeds appear 14 and 16 days later, respectively with seeds having a mass greater than $2 \mathrm{~g}$ and those having a mass less than $1 \mathrm{~g}$. This result reflects a slight influence of the mass of the seed on the germination delay.

\section{Germination Rate (GR)}

Unlike the germination delay, the germination rate was significantly influenced by the mass of seeds used as seed. The germination rate obtained with seeds with a mass greater than $2 \mathrm{~g}$ was $91 \%$ (Fig. 3). Seeds with a mass of less than $1 \mathrm{~g}$ recorded a germination rate of $45 \%$. The comparison of the germination rates by Student's $t$ test revealed a significant difference between the germination rates recorded $(\mathrm{p}<0.05)$.

\section{Speed of Germination ( $S G$ )}

The speed of germination of the large seeds was 17.5 days. This speed could not be determined for the small seeds tested due to its germination rate of less than $50 \%$.

\section{Survival Rate (SR)}

All of the seedlings from the large seeds tested survived after germination. The survival rate obtained with these seedlings was therefore $100 \%$. As for small seeds, $15 \%$ of the seedlings could not survive. The survival rate obtained was therefore $85 \%$.

\section{Influence of Substrate Type on Germination Parameter}

\section{Germination Delay (GD)}

The shortest germination time was obtained with the seeds germinated in Petri dishes (11 days). Seeds germinated in the sand recorded a germination time of 15 days. Seeds sown in lowland soil and forest soil occupy the third and fourth place, respectively, with germination times of 17 and 20 days.

\section{Germination Rate (GR)}

The analysis of the results revealed that the germination rate is significantly affected by the nature of the substrate used. Indeed, the highest germination rate $(99 \%)$ was obtained with seeds germinated in petri dishes. The germination rate of seeds sown in the lowland soil was $79 \%$. Seeds sown in forest soil and in sand recorded germination rates of 60 and $47 \%$, respectively. A significant difference was detected between the different germination rates $(\mathrm{p}<0.05)$.

\section{Speed of Germination ( $S G$ )}

The Mean Germination Time (MGT) was 16 days for seeds tested in the laboratory and 19.5 days for seeds sown in lowland soils. Seeds sown in forest soils had a mean germination time of 23.5 days. This rate could not be determined for seeds sown in sand. The analysis of variance indicated that the nature of the substrate significantly influenced the germination speed $(\mathrm{p}<0.05)$. The evolution of the cumulative germination rate as a function of the number of days after sowing is shown in Fig. 3.

\section{Survival Rate (SR)}

The evaluation of the survival rate of seedlings revealed that this parameter is influenced by the type of substrate used. The overall survival rate was $87.75 \%$ for all germinated seedlings. Seeds germinated in the sand and in the laboratory remain the only treatments that have recorded mortality rates. However, the mortality rate 
was higher for seedlings germinated in sand. The survival rate was 54\% for seedlings germinated in the sand and $97 \%$ for seedlings germinated in the laboratory.

\section{Monitoring of Seedling Growth in Nursery}

The comparative study of the growth of the seedlings resulting from the seeds of different masses was significantly influenced by the mass of the seeds used for sowing. Indeed, at the end of the six months of observation the average growth of the seedlings resulting from the large seeds reached $12.07 \pm 1.42 \mathrm{~cm}$ and that of the small seeds was of $6.19 \pm 0.95 \mathrm{~cm}$ that is to say respective monthly speeds of growth of $0.6 \mathrm{~cm}$ and $0.085 \mathrm{~cm}$.

Regarding the nature of the substrate, the results revealed that the seedlings evolving on the lowland soil develop better than those evolving on the forest soil and on the sand. The average growth recorded at the end of the six months of follow-up is $10.26 \pm 1.4 \mathrm{~cm}$ with the lowland soil, $8.72 \pm 1.23$ $\mathrm{cm}$ and $5.39 \pm 0.55 \mathrm{~cm}$ with the forest soil, i.e., monthly growth rates of $1.71 \mathrm{~cm}, 1.45 \mathrm{~cm}$ and $0.88 \mathrm{~cm}$ respectively. The Table 1 presents the results of the growth parameters of the seedlings recorded after a follow-up of 6 months.

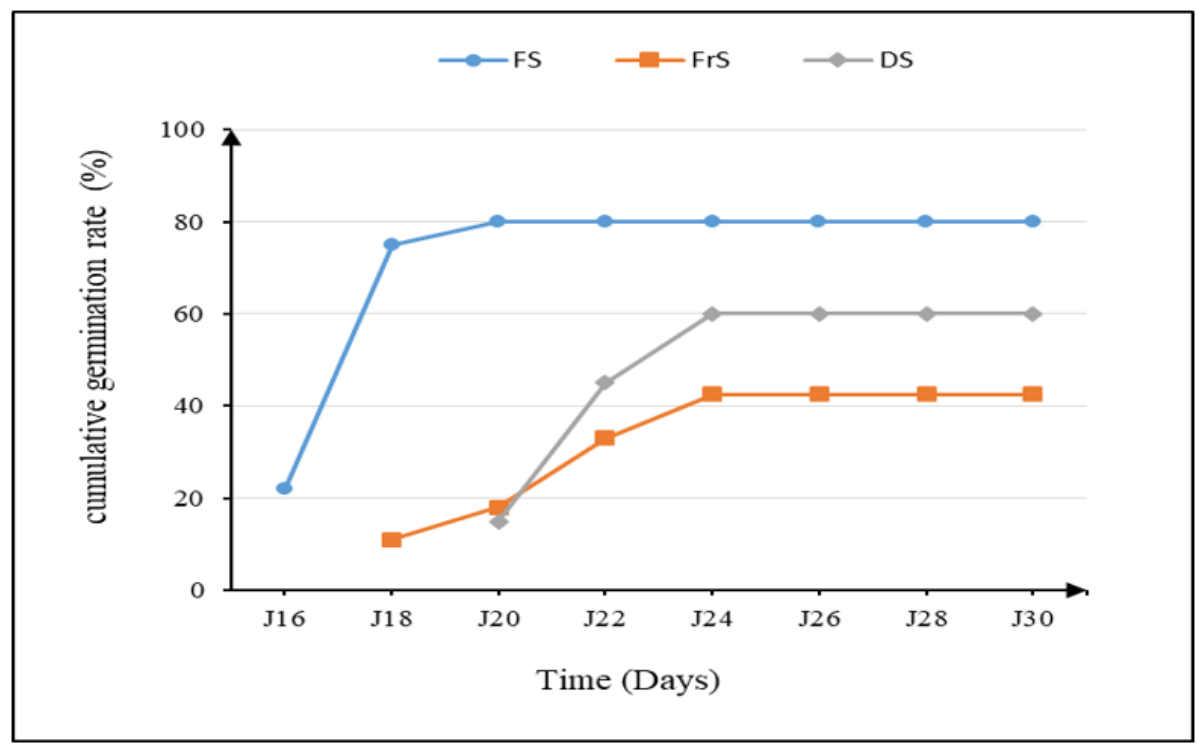

Fig. 2 : Curve of evolution of the cumulative germination rate of the type of seed according to time FS: Fresh Seeds; DS: Dried Seeds; FrS: Frozen Seeds

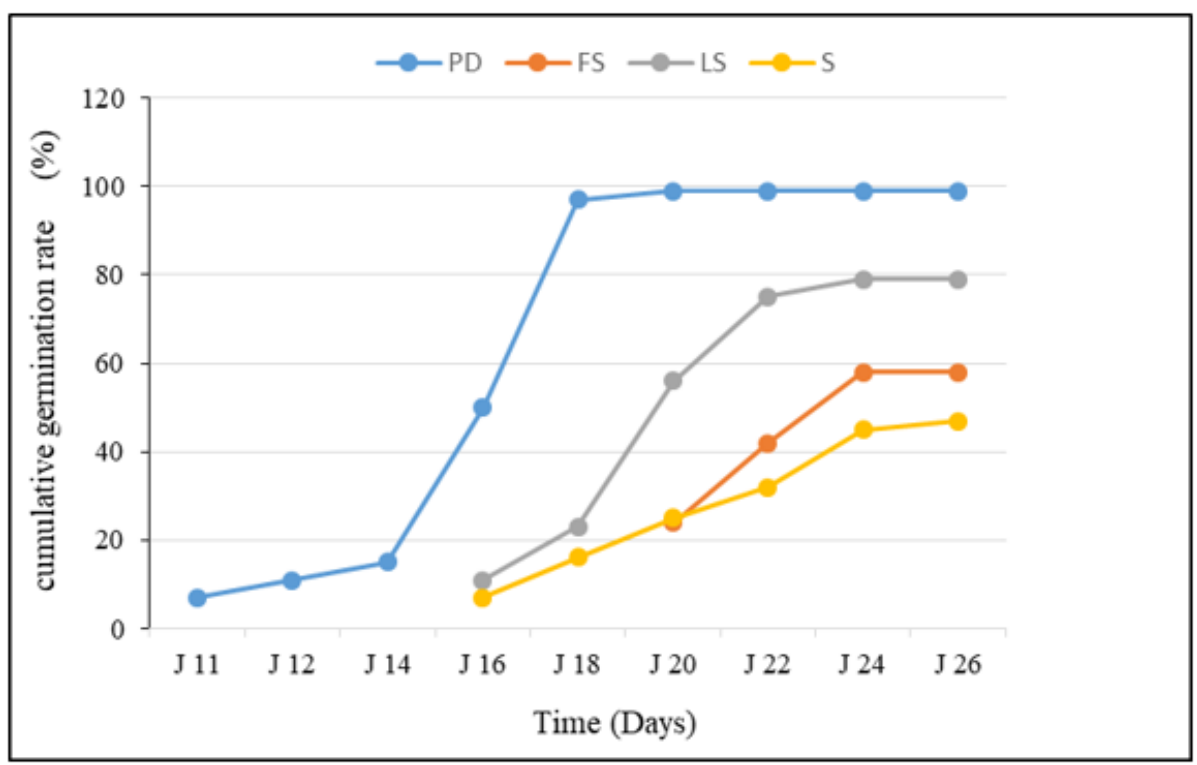

Fig. 3: Curve of evolution of the cumulative rate of germination of the type of seeds of G. mangostana on various substrates according to time PD: Petri Dishes: SF: Forest Soil; LS: Lowland Soil; S: Sand 
Haba Jean Florent et al. / American Journal of Agricultural and Biological Sciences 2021, Volume 16: 50.57 DOI: 10.3844/ajabssp.2021.50.57

Table 1: Effect of mass and substrate type on growth parameters of Garcinia. mangostana seedlings

\begin{tabular}{|c|c|c|c|c|c|c|}
\hline Factors & Type of treatment & Stem height $(\mathrm{cm})$ & Average speed (cm/month) & Leaf length $(\mathrm{cm})$ & Leaf width $(\mathrm{cm})$ & Root length $(\mathrm{cm})$ \\
\hline \multirow[t]{2}{*}{ Mass of seed } & $\mathrm{LS}$ & $12.07 \pm 1.42 \mathrm{a}$ & 2.011 & $5.02 \pm 0.36 \mathrm{a}$ & $3.95 \pm 0.22 \mathrm{a}$ & $14.80 \pm 0.45$ \\
\hline & SS & $6.19 \pm 0.95 b$ & 1.031 & $3.77 \pm 0.13 b$ & $2.71 \pm 0.17 \mathrm{a}$ & $6.93 \pm 1.73$ \\
\hline \multirow[t]{2}{*}{ Type of substrate } & $\mathrm{SF}$ & $8.72 \pm 1.23 b$ & 1.45 & $5.22 \pm 0.14 \mathrm{a}$ & $3.8 \pm 0.54 \mathrm{a}$ & - \\
\hline & S & $5.39 \pm 0.55 b$ & 0.88 & $4,21 \pm 1.55 \mathrm{a}$ & $3.13 \pm 1.11 \mathrm{a}$ & - \\
\hline
\end{tabular}

LS: Large Seeds; SS: Small Seeds; SF: Forest Soil; LoS: Lowland Soil; S: S and the values assigned the same letter are not statistically different $(\mathrm{p}>0.05)$

\section{Discussion}

The results of these trials clearly showed the influence of the type of seed used on the germination parameters studied. Indeed the fresh seeds more humid recorded the best germination time, germination rate and germination speed. The reduction of the rate of germination from 80 to 60 then to $42.5 \%$ respectively with the dried seeds and preserved in the freezer could be due on the one hand to the loss of water by the cores during the drying and on the other hand by the time of conservation in the freezer too prolonged. This result lets appear a very strong influence of the moisture content of seeds on the process of germination of the seed of Garcinia mangostana L. The humidity of the fresh seeds would have contributed to the imbibition of the tissues of the seed thus supporting the hydrolysis and the degradation of the tissues of reserves in simple and assimilable forms. It is therefore the accessibility to these compound by the seed embryos that would be at the origin of seed germination. These results corroborate those of Agyili et al. (2007) who obtained similar results with Garcinia kola seeds. These authors found a significant reduction in the germination capacity of Garcinia kola seeds as soon as their water content was reduced (>30\%). Quenzar et al. (2001) also noted a reduction in viability of Grewia coriacea seeds from 80 to $60,48,24$ and $0 \%$, respectively at one, two, three and four weeks after storage. In terms of storage, the time the seeds were kept in the freezer would have been too long and would have caused the loss of germinative power of the seeds. This conservation would have had a more marked effect on the viability of the embryonic axes of the seeds. This result agrees with those of Benmahioul et al. (2010) who found that the germination of Pistacia vera $\mathrm{L}$ seeds went from $100 \%$ with freshly harvested seeds to 87.3 and $30.9 \%$ with seeds stored for 12 and 18 months respectively. On the other hand, Jiofack and Dondjang (2007) noted that low temperatures maintain the germination capacity of Tetracarpidium conophorum (Euphorbiaceae) seeds in proportions close to those of freshly harvested seeds. This difference could be due to the different nature of the seeds used and the temperature of conservation of the seeds. Indeed for this study the temperature used for the conservation $\left(-4^{\circ} \mathrm{C}\right)$ was lower than that used by these authors.

The seeds of masses higher than $2 \mathrm{~g}$ recorded the shortest time of germination (14 days) and the best rate of germination $(91 \%)$, contrary to the seeds of masses lower than $1 \mathrm{~g}$ for which these values were of 16 days and $45 \%$ respectively for the delay and the rate of germination of seeds. The results obtained clearly show the influence of seed mass on germination parameters in Garcinia mangostana. They could result from the intrinsic conditions of the seeds used. The maturity and the favorable physiological predisposition of the large seeds would have favored a better germinative capacity of the latter. In the larger seeds, the embryos would have a certain ability to germinate and emit roots. Unlike large seeds, small seeds (less mature) tend to abort once planted. The results of this study are similar to those of Bourdeautf and Moreuil (1970) who showed the influence of the mass of the Garcinia mangosteen seed on the germination rate. The germination rates obtained by these authors were 97 and $78 \%$ respectively with large and small seeds.

Concerning the influence of the type of substrate, the results obtained showed a significant effect of this factor on the germination parameters of the Garcinia mangostana seed. Indeed, the germination rates obtained with the different substrates used were $99 \%$ with petri dishes (germination in the laboratory), $79 \%$ with the lowland soil, $60 \%$ with the forest soil and $47 \%$ in the sand. This study shows a very good ability of Garcinia mangostana seeds to germinate in petri dishes under controlled conditions. These results would be the cause of the extrinsic conditions of germination created inside the Petri dishes. The germination of Garcinia mangostana seeds would be very strongly influenced by temperature and humidity. The humidity and the heat of the Petri dishes would have started in a joint way the metabolic reactions at the origin of the germination. It is thus rightly that germination carried out in the lowland soil (more humid), recorded rates and of germination higher than those obtained with the forest soil and the sand which would have a weak capacity of retention in water. Also, the good sanitary condition of the environment and of the sown seeds could explain these results. Indeed, once buried in the soil, the seeds are exposed to pathogens and are often attacked by insects. Seeds germinated in petri dishes would therefore be less exposed to pathogens or attacked by pests. According to Niang et al. (2010) and Martine et al. (2011), decreases in germination rates and high seed mortality would be related to bacterial, fungal and insect attacks.

The comparative study of the growth of seedlings from seeds of different masses and evolving on different 
substrates showed on the one hand that the seedlings from large seeds develop better, grow faster and are more vigorous than those from small seeds. On the other hand, the study showed that the seedlings growing on the lowland soil developed better than those growing on the forest soil. These results are believed to be due to the physico-chemical properties of the soil used. The clay texture and mineral composition of the lowland soil (richer in phosphorus) would be more favorable to the growth of mangosteen seedlings through root emission. The lowland soil would provide the seedlings with the water and mineral elements necessary for their development. Also, the relatively higher humidity of the lowland soil could explain these results. The mangosteen tree is a late-growing plant that has difficulty resisting drought and that requires particularly high humidity conditions for its development. Hume and Cobin (1946) and Havard (1950) report that soils with 60 to $75 \%$ clay content were favorable to the development of mangosteen trees.

\section{Conclusion}

The germination of the seed of Garcinia mangostana is significantly influenced by the type of seed, the mass and the type of substrate used. The study carried out revealed that the freshly harvested seeds give better delay, speed and rate of germination than the dried or preserved seeds. As for the type of substrate, the highest germination rate was obtained with the seeds put to germinate in Petri dishes. As for the follow-up of seedlings in the nursery, those from seeds with a mass greater than $2 \mathrm{~g}$ growing on the lowland soil recorded the best performance. These seedlings grew faster and were more vigorous.

\section{Author's Contributions}

The contribution of the authors was at all levels from the conduct and realization of the work to the writing of the manuscript.

Haba Jean Florent: Conducted the trials collected the data, analyzed the results and was one of the main editors of the manuscript.

Phaceli Elichama Desirée, Silué Nakpalo: Helped carry out the protocol and conduct the trials.

Dembele Ardjouma, Koffi Kouao Jean: Were the investigators of the research project and were the artisans of its implementation by creating the carder of its realization. They also supervised the wrinting of the manuscript.

\section{Ethics}

This article is original and contains unpublished material. The corresponding author confirms that all of the other authors have read and approved the manuscript and no ethical issues involved.

\section{References}

Agyili, J., Sacande, M., Koffi, E., \& Peprah, T. (2007). Improving the collection and germination of West African Garcinia kola Heckel seeds. New Forests, 34(3),

269-279. http://link.springer.com/article/10.1007/s11056-0079054-7

Ahoussi, K. E., Koffi, Y. B., Kouassi, A. M., Soro, G., Soro, N., \& Biémi, J. (2013). Étude de la variabilité hydroclimatique et de ses conséquences sur les ressources en eau du Sud forestier et agricole de la Côte d'Ivoire: Cas de la région d'Abidjan-Agboville. International Journal of Pure \& Applied Bioscience, 1(6), 30-50.

https://www.scirp.org/reference/referencespapers. aspx? referenceid $=264537$

Benmahioul, B., Khelil, B., Kaïd-Harche, M., \& Daguin, F. (2010). Étude de la germination et de l'effet du substrat sur la croissance de jeunes semis de I L. Germination study and substrate effect on the growth of young seedlings of Pistacia vera L. Acta Botanica Malacitana, 35, 107-114. doi.org/10.24310/abm.v35i0.2865

Berka, S., \& Harfouche, A. (2001). Effets de quelques traitements physico-chimiques et de la température sur la faculté germinative de la graine d'Arganier. Revue forestière française. doi.org/10.4267/2042/5219

Bita, A., Mpika, J., Saya, R.A., Ngantsoue, L., Attibayeba (2017). Evaluation des conditions de germination des noyaux de Grewia coriacea Mast. (Malvaceae). Int. J. Biol. Chem. Sci. 11(6): 2809-2825. doi.org/10.4314/ijbcs.v11i6.20

Bourdeaut, J., \& Moreuil, C. (1970). Le mangoustanier. Ses possibilités de culture en Côte d'Ivoire et à Madagascar. Fruits, 25(4), 223-245. https://agritrop.cirad.fr/421584/1/document_4215 84.pdf

Dembélé, A. (2013). Technique de production du mangostanier (Garcinia mangostana L, Clusiaceae), Itinéraire Technique Conservation Poste-récolte des fruits et normes du Codex alimentarus. Laboratoire National d'Appui au Développement Agricole, fiche technique, p 27.

Havard, D.B. (1950). Le mangostanier. Fruits, Paris, vol.5, n 5 , p 161-166.

Hume, E. P., \& Cobin, M. (1946). Relation of seed size to germination and early growth of mangosteen. Proceedings of the American Society for Horticultural Science (EUA) v. 48 p. 298-302. http://www.sidalc.net/cgi-

bin/wxis.exe/?IsisScript=orton.xis\&method=post\&f ormato $=2 \&$ cantidad $=1 \&$ expresion $=\mathrm{mfn}=050004$ 
Jiofack, RB, \& Dondjang, JP (2007). Characterization and study of the germination of diaspores of Tetracarpidium conophorum (Müll. Arg.) Hutch. and Dalz. International Journal of Biological and Chemical Sciences, 1 (2), 136-142. doi.org/10.4314/ijbcs.v1i2.39683

Karim, N., Rahman, M. A., Changlek, S., \& Tangpong, J. (2020). Short-time administration of xanthone from Garcinia mangostana fruit pericarp attenuates the hepatotoxicity and renotoxicity of type II diabetes mice. Journal of the American College of Nutrition, 39(6), 501-510. doi.org/10.1080/07315724.2019.1696251

Kondo, M., Zhang, L., Ji, H., Kou, Y., \& Ou, B. (2009). Bioavailability and antioxidant effects of a xanthonerich Mangosteen (Garcinia mangostana) product in humans. Journal of agricultural and food chemistry, 57(19), 8788-8792. doi.org/10.1021/jf901012f

Laouali, A., Dan Guimbo, I., Youchaou, A., Rabiou, H., \& Mahamane, A. (2015). Etude de la germination de la graine et suivi de la croissance en pépinière de Prosopis africana (G. et Perr.) Taub., espèce menacée de disparition au Niger. In Annales de l'Université Abdou Moumouni de Niamey (Vol. 18, pp. 1-12). https://www.researchgate.net/publication/282778294

Lim, Y. S., Lee, S. S. H., \& Tan, B. C. (2013). Antioxidant capacity and antibacterial activity of different parts of mangosteen (Garcinia mangostana Linn.) extracts. Fruits, 68(6), 483-489. doi.org/10.1051/fruits/2013088

Martine, B. M., Eugène, K. K., Roger, K. K., Mongomaké, K. O. N. É., Justin, K., \& TanohHilaire, K. O. U. A. K. O. U. (2011). Influence des conditions de stockage et de la durée de chauffage sur la capacité de germination des graines du palmier à huile (Elaeis guineensis Jacq.). Journal of Applied Biosciences, 41, 2780-2787. http://www.m.elewa.org/.../5.pdf
N'guessan, K. A., Diarrassouba, N., Koné, B., Alui, K. A., Yao, K. A. (2015). Caractérisation morphopédologique et contraintes au développement de Lippia multiflora sur deux sols tropicaux de Côte d'Ivoire. Journal of Animal and Plant Sciences, 24 (3): 3814-3828. http://www.m.elewa.org/JAPS

Niang-Diop, F., Sambou, B., \& Lykke, A. M. (2010). Contraintes de régénération naturelle de Prosopis africana: facteurs affectant la germination des graines. International Journal of Biological and Chemical Sciences, 4(5). doi.org/10.4314/ijbcs.v4i5.65578

Osman, M., Milan, A. R. Williams, J. T., Smith, R. W., Dunsiger, Z. (2006). Mangosteen, Garcinia mangostana L., thèse Crops, University of Southampton, International Centre for Underutilised Crops, 170p.

Bamba, N., Ouattara, N. D., Konan, D., Bakayoko, A., \& Bi, F. H. T. (2018). Effets de cinq prétraitements sur la germination du vène (Pterocarpus erinaceus Poir., Fabaceae) dans la Réserve du Haut Bandama (Côte d'Ivoire). doi.org/10.19044/esj.2018.v14n30p438

Quenzar, B., Trifi, M., Bouachrine, B., Hartmann, C., Marrakchi, M., Benslimane, A. A., \& Rode, A. (2001). A mitochondrial molecular marker of resistance to Bayoud disease in date palm. Theoretical and Applied Genetics, 103(2-3), 366-370. doi.org/10.1007/s001220100572

Zhang, Y., Wang, F., Zhou, Y., Li, Y., Zhou, T., Zheng, J., Zhang, J., Li, S., Xu, D., Li, H. (2016). Effects of 20 selected fruits on ethanol metabolism: potential health benefits and harmful impacts. Int $\mathbf{J}$ Environ Res Public Health, 13(4):399. doi.org/10.3390/ijerph13040399 